Vol. 11, n 1 | 2007

Varia

Making the Modern Australian Homosexual Male: Queensland's Criminal Justice System and Homosexual Offences, 1860-1954

Clive Moore and Bryan Jamison

\author{
(2) OpenEdition \\ Journals \\ Electronic version \\ URL: https://journals.openedition.org/chs/144 \\ DOI: $10.4000 /$ chs. 144 \\ ISSN: 1663-4837 \\ Publisher \\ Librairie Droz \\ Printed version \\ Date of publication: 1 June 2007 \\ Number of pages: $27-54$ \\ ISBN: 978-2-600-01160-0 \\ ISSN: 1422-0857
}

Electronic reference

Clive Moore and Bryan Jamison, "Making the Modern Australian Homosexual Male: Queensland's Criminal Justice System and Homosexual Offences, 1860-1954", Crime, Histoire \& Sociétés / Crime History \& Societies [Online], Vol. 11, $\mathrm{n}^{\circ} 1 \mid$ | 2007, Online since 01 June 2010, connection on 23 March 2022. URL: http://journals.openedition.org/chs/144 ; DOI: https://doi.org/10.4000/chs. 144

This text was automatically generated on 23 March 2022.

(C) Droz 


\title{
Making the Modern Australian Homosexual Male: Queensland's Criminal Justice System and Homosexual Offences, 1860-1954
}

\author{
Clive Moore and Bryan Jamison
}

"Of an evening I do nothing. I come into town every night. I don't stand at the Queen St corners... I am not a well-known character about the town. I have a good character. I do not know what a 'city queen' is... I am surprised to hear that term is applied to me about the city." William Johns under cross-examination, Brisbane, 1906

Queensland State Archives, SCT/CCC183

\section{Introduction}

1 William Johns' testimony allows us a small window into the homosexual subculture in Australia a century ago. Studies of the history of Western sexuality routinely include American settler societies, but colonial and early twentieth century Australia - Britain in the antipodes - rarely receives mention. However, Australia, viewed through the records of the criminal justice system, makes a good case study of the making of the Western male homosexual. Criminal justice records provide evidence of a wide range of matters pertaining to male same-sex activities and the emergence of modern male sexual and gender identity. Early evidence exists of male couples, and of the use of public space for making sexual contacts. Medical explanations, policing and court enforcement of laws, attitudes to a variety of sexual activities and to the ages of samesex couples, the existence of 'city queens' like William Johns, and the emergence of identity within a homosexual discourse, can all be found in the Australian records. As 
well, the size of the research base for this paper is unique compared to that for any other Australian jurisdiction ${ }^{1}$, and unusually extensive in comparison with any other similar studies in the Western world, particularly for the period when modern homosexual identity was emerging ${ }^{2}$.

2 Britain's Australasian colonies were established between 1788 and the 1830s. Queensland began as a penal outpost of New South Wales in the 1820s, and then became a separate colony in 1859. All achieved self-government between the 1850s and 1890s, and in 1901 the six Australian colonies federated into one nation; while New Zealand choose a separate path. Australian society, at least until the late 1940s and 1950s, when large numbers of migrants were introduced from Continental Europe, was largely of British origin with a legal system based on British precedents. Prosecutions for maleto-male sexual activity in England increased in the early decades of the eighteenth century and prosecutions for sexual activity in public spaces show a marked increase over several decades before organised policing began. Writing in the 1970s, Harvey suggested that this largely involved urban communities and the enlarged lower middle classes, the sectors of English society that expanded rapidly in the eighteenth century ${ }^{3}$. Although some authors suggest that proof of a cognitive change requires more empirical evidence, recent British studies by Randolf Trumbach ${ }^{4}$, Anthony Fletcher (1995) and Rictor Norton (1992) suggest that dramatic changes to gender and sexual patterns occurred after approximately 1700. In line with these British findings, Theo van der Meer (1989) argues that a homosexual subculture had developed in Netherlands urban areas by the 1730s, and Michael Sibalis provides 1700 as an equivalent date for urban France. Homosexuality always existed as a physical act, but was condemned by Christianity as a waste of procreative 'seed'. Increased urbanisation meant that men were able to use public space for same-sex purposes, and when a series of modernising influences led to the reorganisation of gender identity, homosexuality was entrenched as social practice, which facilitated the development of a subculture. The argument is that a new pattern of individual identity emerged and the nature of male same-sex relations altered. Trumbach et al. do not argue that their eighteenth century 'mollies' were the sole ancestors of modern gay-identified men, but they do suggest that effeminate males became increasingly prominent within the sodomite subculture after 1700, and that the elements of what became the dichotomised (hetero/ homosexual) male sexual world were forming. Passive sexual roles were stigmatized, and adolescent males, once available as passive sexual partners, began to be protected by law and medicine. Sodomy had long been viewed as a casual act, but during the nineteenth century homosexuality began to be established as a subcultural identity ${ }^{5}$. Settlement of Australia began soon after these radical gender and sexual changes occurred in Britain. The Australian nation was created during a time when resilient same-sex subcultures were forming in many Western urban areas and sexual identity was becoming a major characteristic of individuals.

3 Although condemned by the authorities, homosexuality was a constant feature of the convict era in Australia (1788-1868). Isolated instances of homosexuality have been located from Queensland's convict years (1824-1842) and a few cases survive from the 1850s, which suggest that Queensland was no different from the other convict and early settler societies in Australia ${ }^{6}$. Australia's colonial immigrant society was substantially rural but with a high concentration in urban areas, and always more egalitarian than British society. Beats (the Australian term for male use of public space for same-sex 
sexual soliciting) in urban areas can be dated back to the 1830s in Sydney and were also in use during the 1860s along the city reaches of the Brisbane River close to ferry terminals. Youths and men seem to have been readily available for sexual encounters, and all through the nineteenth century there is a pattern of 'pickups' in public places relating to public transport, parks, public toilets and street-cruising. Males predominated amongst the early Australian settlers, causing population and gender imbalances that were most marked in rural areas, which suggests that situational homosexuality was probably widespread. Changing gender patterns is a slow and partial process: older gender patterns continued and did not entirely disappear. Based on benchmark studies such as George Chauncey's Gay New York (1994) or Elizabeth Kennedy and Madeline Davis's Shoes of Leather, Slippers of Gold (1993), distinct class and ethnic differences slow or speed the adoption of gender and sexuality changes. Oldstyle bisexual libertines steeped in pre-modern patterns may have survived in the colonies in the nineteenth century, their orientation perhaps cloaked by marriages, or in predominantly male communities which turned a blind-eye to the deviant sexual activities of the elite. Studies such as those of Robert Aldrich ${ }^{7}$ and Rudi Bleys (1995) indicate that Europe's outposts were a place of escape for many who left home "for the good of their health and their country"s. Misfits within stricter European society, including even the occasional effeminate English lord, coped well enough in the colonies'. Chauncey suggest that gay 'faries' existed in New York as early as the 1870s (possibly the cultural ancestors of the 'mollies' from eighteenth century London), that a highly visible gay male culture existed in New York by the 1890s, which by the 1930s could be described using the spatial metaphor of a "gay world". Chauncey also argues that hetero-homosexual binarism is a recent creation, dated to the middle of the twentieth century. Before this, same-sex relations were only regarded as 'queer' if they displayed broader inversion of gender status ${ }^{10}$.

4 In a similar pattern to that describe by Chauncey and others, Australian research has revealed cases of long-term intimate relations and same-sex use of public space for sexual purposes, followed by development of a small but discernable homosexual male subculture in the 1890s and 1900s, which became well-established in large cities by the 1920s and $1930 \mathrm{~s}^{11}$.Changes in criminal law largely followed the British precedent and because of similarities in the two societies, share similar motivations. This paper compares homosexual offences recorded in the criminal justice system of one Australian jurisdiction- Queensland- with the development of male same-sex relationships in other societies, and draws conclusions some of which are unique to Australian circumstances, while others support patterns established elsewhere.

\section{Queensland and the Research Methodology}

Queensland covers of $22.5 \%$ of Australia - roughly the same area as the British Isles and Western Europe combined, or five Japans, or two and a half Texases. The indigenous population was around 120,000 before introduced diseases and settler violence rapidly depleted the original inhabitants to just tens of thousands by the end of the nineteenth century. In 1859, the European population was 28,000 , of whom 6,000 resided in Brisbane. Throughout the ninety-five years under examination, overwhelmingly the population derived from the British Isles, although there was also a declining but significant indigenous community, as well as substantial numbers of Asian and Pacific 
Islander immigrants. This racial mix also allows us to consider inter-racial male-tomale sexual activity.

6 The basis of this study derives from a period of extensive research between 1992 and 1995 in the Jus/S1-8 Series of the Criminal Registers held at the Queensland State Archives in Brisbane, which was used initially to write social history ${ }^{12}$. The court case evidence from which these statistics on male-to-male sexual offences in both the colonial and post-colonial periods of Queensland history were gathered, is found in several levels of the court system. When a complaint reached the police, it was investigated and if the evidence seemed sufficient, the matter proceeded to a Police Magistrate at a Court of Petty Sessions hearing, which could also sit as a Police Court. Most of the detailed evidence is contained in transcripts of interviews obtained in the initial investigation. If a Magistrate decided that there was a charge to answer, he scheduled the case for a superior court hearing in front of a judge and twelve-man jury, either at the Supreme Court based in the major coastal centres of Brisbane, Rockhampton or Townsville, or at its Circuit Courts that travelled to smaller urban centres every few months. Queensland's Supreme Court was declared in 1861, while the District Circuit Courts were established in 1866 to ease the load on the Supreme Court and better serve the regions of the vast colony. Appeals could be made from the District Court to the main Supreme Court.

7 The research yielded 548 male-to-male sex court cases and 464 convictions over the ninety-five years. The statistical analysis is based on the convictions. Some caveats are needed to cover decisions made in creating these statistics and to explain possible gaps in the records. The cases are a criminal law point estimate, not an indication of the actual level of homosexual activity in Queensland. There was a reticence to bring cases involving homosexuality and bestiality before the courts, more so than with cases involving other sexual offences ${ }^{13}$. These male-to-male sexual activity cases are only the tip of the proverbial ice-berg, and we have no idea how deep our ice-berg extends below the surface. As well, the vicissitudes of archival practices and management in the nineteenth and early-mid twentieth century, and devastating Brisbane floods of 1974 which affected the State Archives, means that a considerable body of material has been lost to historians forever, including in all probability a number of cases relating to male-to-male sexual activity. However, the vast majority of cases are included in the statistics, and at the very least they represent a large proportion of the total number of similar cases in the period under consideration - probably at least $90 \%$. They allow us to discern significant trends and patterns in the history of the relationship between male-to-male sex activity and the criminal justice system, and to read into them trends that can be tested in other jurisdictions.

All 548 cases provide useful evidence for writing the social history of male sexuality, but only those where a verdict was delivered have been included in the statistical tabulations. The statistics are based only on the convictions for male-to-male sexual activity and exclude bestiality convictions. Bestiality is grouped with male-to-male sexual activity under the early Acts, but as the paper's focus is on the emergence of male homosexual identity, and Collins has published on bestiality ${ }^{14}$, a decision was made to exclude bestiality from the statistics. 'No True Bill' (meaning that, after the committal for trial but before the case reached the court, the Crown chose not to proceed) and 'Nolle Prosequi' decisions (where the prosecutor agreed to proceed no further after a trial had commenced) were also excluded, even though they were quite 
common solutions to cases. While the magistrate's court evidence in many of the 'No True Bill' and 'Nolle Prosequi' cases often looked damning, the cases did not proceed to a conclusion in the higher court, and the documentation is too incomplete to be of much use. Having said all of this, the 464 cases have world-wide significance in the study of the state regulation of the development of homosexual identity.

For the most part, these statistics are divided neatly between the colonial years (1859-1900) and post-colonial (1901-1954); the 1954 cut-off is due to archival access policy. This periodic division was adopted, not in acknowledgment of a rupture in the continuum of Queensland's history following Australian national unification and partial independence from the United Kingdom. Rather, the colonial and post-1901 periods conform to the contours of legislative enactments that impacted significantly on maleto-male sexual activity as defined by the criminal justice system.

\section{The Law and Homosexual Offences in Queensland}

10 Despite the introduction of minor amending legislation ${ }^{15}$, the periods were defined by two major Acts of Parliament, one spanning the years 1865 to 1900 and the other operating from 1901 to 1954 and beyond to 1990. British colonies took their lead from English law. The relevant legislation when Queensland began to be settled but was still part of New South Wales (1824-1859), and up to the first few years as a separate colony (1859-1865), was an 1828 English Act ${ }^{16}$.The legislation concentrated on anal intercourse and did not specify other homosexual practices, which were usually dealt with as misdemeanours. In 1861 Britain abolished the death penalty for all crimes except murder and high treason, which removed the ultimate penalty from the "abominable crime" of sodomy. Queensland adopted this legislation in 1865. Ross Barber, writing on capital punishment in early Queensland, says that early sodomy cases were always commuted because the act was considered to be non-violent ${ }^{17}$. Similarly, Michael Sturma, commenting on New South Wales in the mid-nineteenth century, states:

Although legally sexual offences were regarded with as much abhorrence as murder, only a small proportion of those people convicted were sentenced to death, and a smaller proportion still were actually executed ${ }^{18}$.

11 There is no record of any executions for sodomy in Queensland between 1824 and 1865. The last execution for sodomy in England was in 1835, and generally executions for crimes (other than murder) in the British legal system had ceased by the $1840 \mathrm{~s}^{19}$. Sturma's statistics suggest that few people were found guilty of sodomy or bestiality in New South Wales during the 1840s and 1850s, and all of these were sentenced to prison terms of less than three years. He also concluded that in practice all convictions for "unnatural offences" were punished more leniently than the law specified, which is similar to the Queensland findings for 1860-1954. Only one sodomy-related death sentence occurred in Queensland. In 1864 a man was convicted for sodomy of a woman at Maryborough, but the death penalty was commuted.

In 1865, Queensland passed legislation entitled An Act to Consolidate and Amend the Statute Law of Queensland Relating to Offences Against the Person (29 Vic. No.11) (hereafter the 1865 Act),closely modelled on the 1861 Imperial Offences Against the Person Act,which abolished the death penalty for anal intercourse with a human or animal (termed "buggery" in the Act), and introduced the new crime of intention to commit anal intercourse. The relevant clauses of the 1865 Act are Sections 62 to 64, gathered under 
the heading "Unnatural Offences". Essentially, the Act contained provisions to punish three homosexual offences: the "abominable crime of buggery" (with either human or animal); any "attempt to commit the said abominable crime", and indecent assault.

The 1861 Imperial Offences Against the Person Act was indirectly supplemented in 1885, by the Criminal Law Amendment Act, which included a clause to protect women and children and suppress brothels-so-called Labouchere amendment, which stated:

Any male person who, in public or private, commits, or is a party to the commission of, or procures or attempts to procure, the commission by any male person of, any act of gross indecency with another male person, shall be guilty of a misdemeanour, and being convicted thereof shall be liable at the discretion of the court to be imprisoned for any term not exceeding two years, with or without hard labour (C. 11).

This amendment is often taken as evidence that lawmakers were aware that a homosexual subculture existed in London and other British cities, but Henry Labouchere seems to have been trying to derail other amendments to the Act by showing that they were just as absurd as any attempt to police his amendment ${ }^{20}$. Inadvertently, the new law also assisted attempts at blackmail and was used in 1895 to convict Oscar Wilde on the evidence of male prostitutes acting as police informers. Whatever Labouchere's reason for proposing the addition to the Act, despite the usual flow-on of similar British Acts to the colonial legislatures, the clause was not immediately adopted in Australia. In 1891, when Queensland passed its version of the 1885 British Act, Labouchere's amendment was excluded. The reason for this exclusion is unknown, but the clause was eventually included as "Indecent Practices between Males" in the 1899 revision of the Queensland Criminal Code ${ }^{21}$.

In 1899, An Act to Establish a Code of Criminal Law (hereafter the 1899 Act) was assented to by the Governor of Queensland, and became operative from the first day of January, 1901. Sir Samuel Walker Griffith, a Welsh-born Queensland politician and legal expert, wrote this Act. Elected to the Legislative Assembly in 1872, and a member of Cabinet from 1874, Griffith was Premier during 1883-1888 and 1890-1893, after which he became Chief Justice of Queensland, and finally Chief Justice of Australia between 1903 and $1919^{22}$. In the late 1890s, Griffith set himself the ambitious task of rationalising the criminal code in all its particulars, including male-to-male sexual activity. The code as it appeared in legislative form contained four Sections, 208-211, relating to male-tomale sexuality. Sections 208 and 209 closely resemble those pertaining to anal intercourse in the previous legislation, although the sentences were reduced. Section 208 dealt with anal intercourse: a guilty verdict under this section delivered a prison sentence of up to fourteen years with hard labour. Section 209 allowed for a sentence of up to seven years with hard labour for any attempt to commit anal intercourse. Section 210 specified a prison term of up to seven years with hard labour to punish the "Indecent Treatment of Boys Under Fourteen". Section 211 dealt with "Indecent Practices between Males" and provided for the conviction of acts of "gross indecency" perpetrated either in public or private, which usually meant oral sex or masturbation. The offence was deemed a misdemeanour with a possible sentence of up to three years imprisonment, with hard labour.

16 These laws remained in force until 1990 when a Labor government replaced a conservative government that had held power since 1957. Even so, the gay political lobby still had to embarrass the new government into honouring its reform 
commitments ${ }^{23}$. Having outlined the legislation affecting male-to-male sexual activity, it is appropriate to begin an analysis of the various statistical categories deployed.

\section{Statistical Categories}

17 The data on the 464 convictions is organised by offence and then broken down into the sub-categories including the regions and time periods in which the charges were brought forward, and, where possible, the age of the defendant. Also, findings include comments on the severity of sentences over time and, again, where possible, the relationship to the age of the defendant. Finally, there are brief comments on the possible influence of the judges and juries on proceedings.

After the singular 1864 conviction for sodomy of a woman, all other convictions for anal intercourse and attempted anal intercourse only involve men. These convictions straddle the colonial and post-1901 periods, allowing a long-term appraisal of the ways in which the criminal justice system dealt with these charges. As well, through the extra categories included in the 1899 Act, it is possible to gain, over the half-century time-span of this survey, some appreciation of changing patterns in the occurrence of such offences and their treatment by the criminal justice system during the first half of the twentieth century.

\section{The Influences of Time Period and Region}

Reflecting population growth for the colony/state - an expansion from 28,000 immigrant residents in 1859 to $1,318,000$ in 1954 - the vast majority of cases were tried in the post-Federation period, with $80 \%$ of the total number of cases occurring between 1901 and 1954. The manner in which Queensland developed - with a dominant capital city in the southeast corner (Brisbane had a population of 6,051 in 1859 and 502,320 in 1954), supported by substantial coastal settlements - probably made police surveillance and investigation of the activities, and the apprehension of offenders, much easier in urban areas than in the far flung rural districts ${ }^{24}$.

Chart One: Queensland Courts: Percentages of Cases Heard 1860-1900

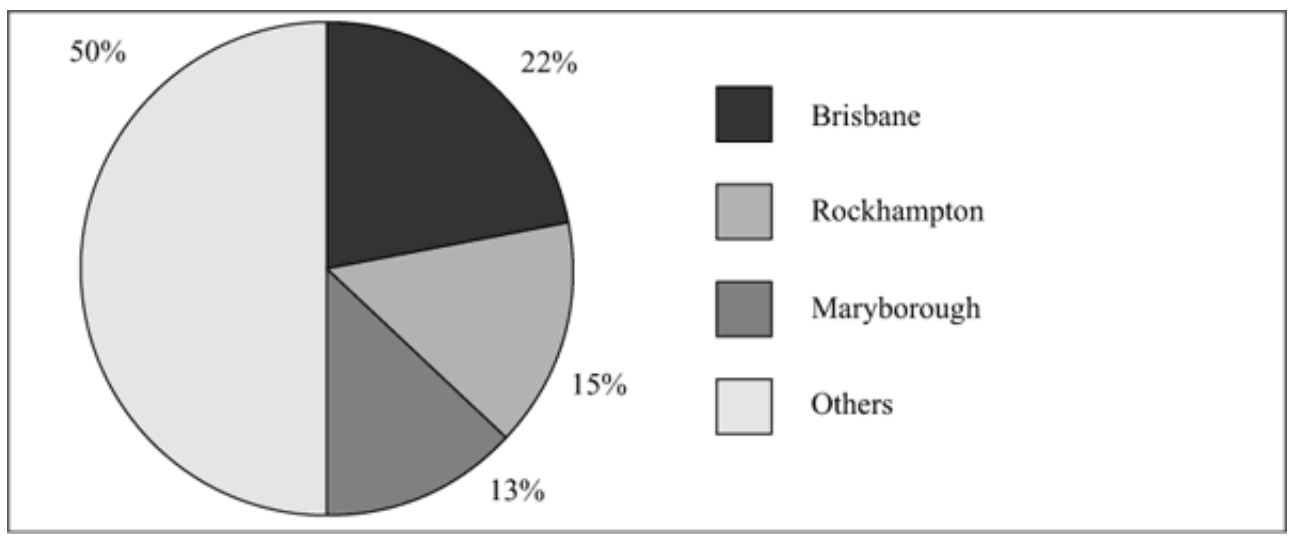


Chart Two: Queensland Courts: Percentages of Cases Heard 1901-1954

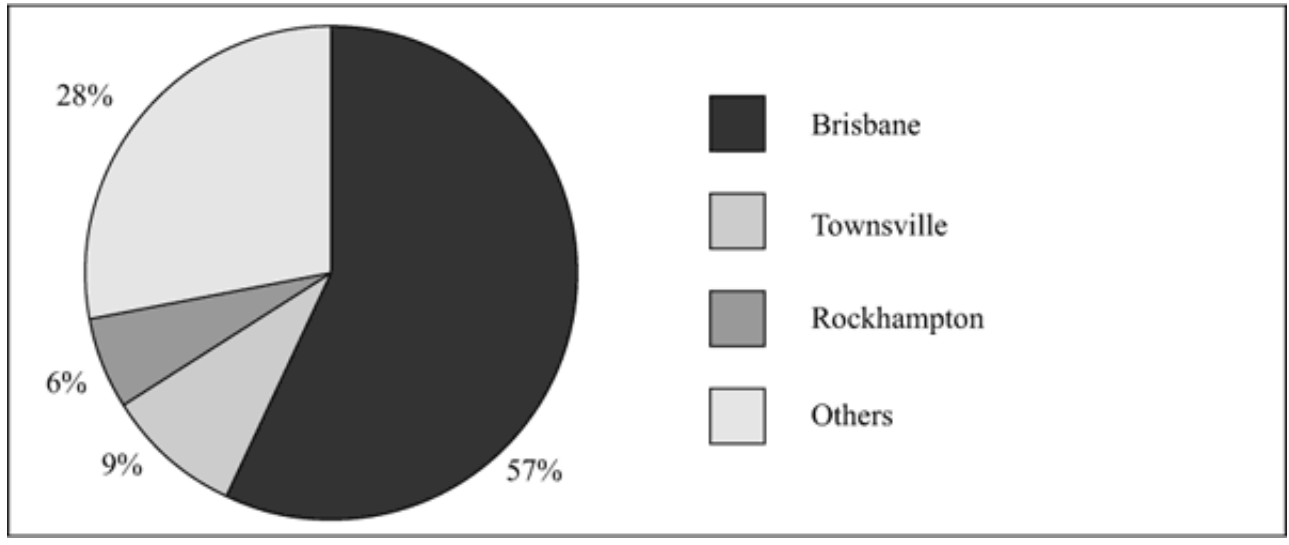

The pattern in the spread of cases conforms to the growth of Queensland's urban centres. From 1860 to 1900, male-to-male intercourse and attempted male-to-male intercourse were the only categories in the Act. Chart One shows that convictions were fairly evenly spread, although they preponderate in the south of the colony and on the central coast, which reflects settlement patterns. Of the total prosecutions, $22 \%$ were tried in Brisbane, $13 \%$ were tried in Maryborough (a southern coast medium size sugar town), and $15 \%$ in Rockhampton (a central coast cattle town and regional administrative base). The remaining $50 \%$ of cases were heard in fifteen regional courts.

Chart Two shows the post-Federation years, when there was a larger range of categories. Reflecting the growing importance of Brisbane as a burgeoning legal and population center, $57 \%$ of all cases were heard in Brisbane, with the remainder spread throughout the State. Townsville had become the center for the northern regional court (9\% of the cases), Rockhampton remained significant but had declined in important (6\% of the cases) and Maryborough was no longer a major court base. During the twentieth century, 64\% of "Indecent Practices between Males" cases were heard in Brisbane, with the remaining $36 \%$ heard in thirteen courts throughout the State. Brisbane also dominated the "Indecent Treatment of Boys Under Fourteen" category, with $61 \%$ of cases. The remaining $39 \%$ were held at seventeen courts throughout the State ${ }^{25}$.

Queensland had a high police strength compared to other areas of Australia. Thirty to $40 \%$ of the police force was based in the greater Brisbane area, but the colony/state was so huge that beyond the coastal towns, policing was at a low level. In mid-nineteenth century America and Britain there was a shift from deterrence to detection of serious crime, followed by a marked decline in arrests for indictable offences in the second half of the century. Mark Finnane and Stephen Garton ${ }^{26}$ show that this general pattern was paralleled in Australia. Some of the male-to-male sex cases were reported to police by outraged citizens who happened upon 'unnatural' acts or suspected they were taking place, but there is also evidence from the court cases, back a far as the $1860 \mathrm{~s}$, of police using entrapment techniques, and of police committing perjury to ensure that they achieved a conviction, particularly when it came to proving anal penetration ${ }^{27}$. In 1901, around $22 \%$ of Queensland males lived in Brisbane, $43 \%$ lived in the other coastal urban areas and $35 \%$ lived in rural areas ${ }^{28}$. In some rural districts - mainly pastoral and mining areas - the proportion of males in the population was extreme ( 80 to $99 \%$ ) but there is no indication of commensurately higher charge rates. The spread of cases is in 
proportion to the overall population, with an urban bias, to be expected because of the pattern of policing and the urban nature of the emerging subculture. Most of the cases involve the working or lower middle classes. There is little evidence to suggest increasing sophistication in police detection techniques had anything to do with the changing trends, but the support of medical doctors to prove penetration was constant throughout the whole period.

\section{Overall Findings for Charges}

The defendant's chances of acquittal were poor: just over $70 \%$ of those facing prosecution between 1860 and 1954 were found guilty ${ }^{29}$.

Chart Three: Percentages of Offences Committed 1860-1900

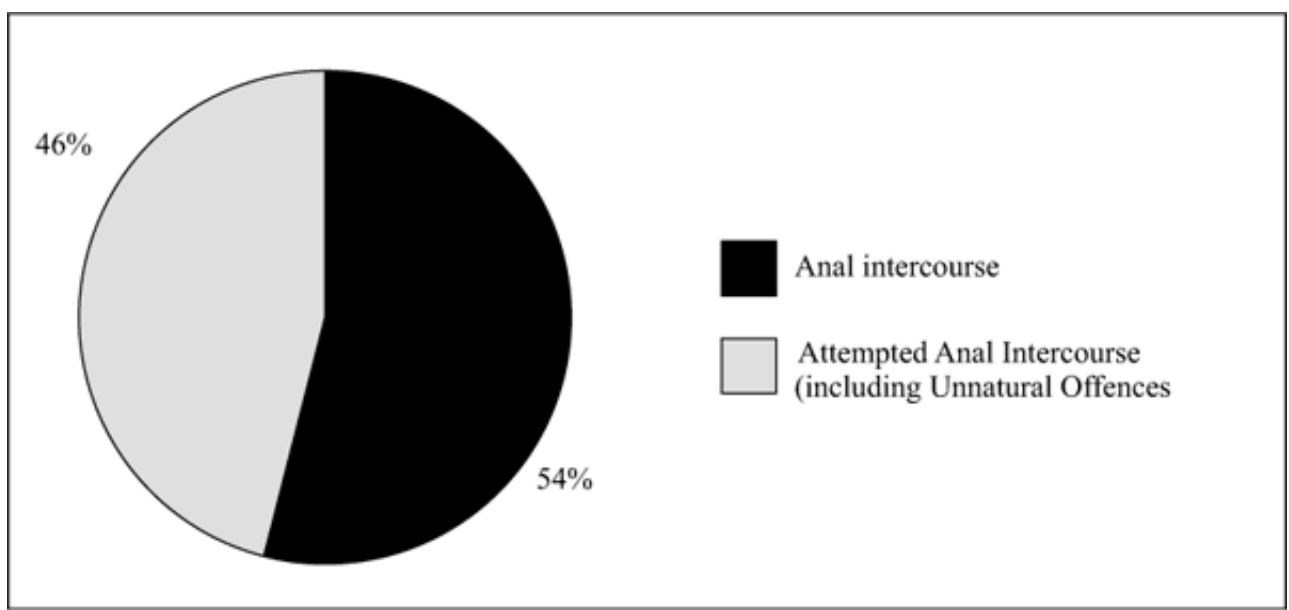

Chart Four. Percentage of Offences Committed 1901-1954

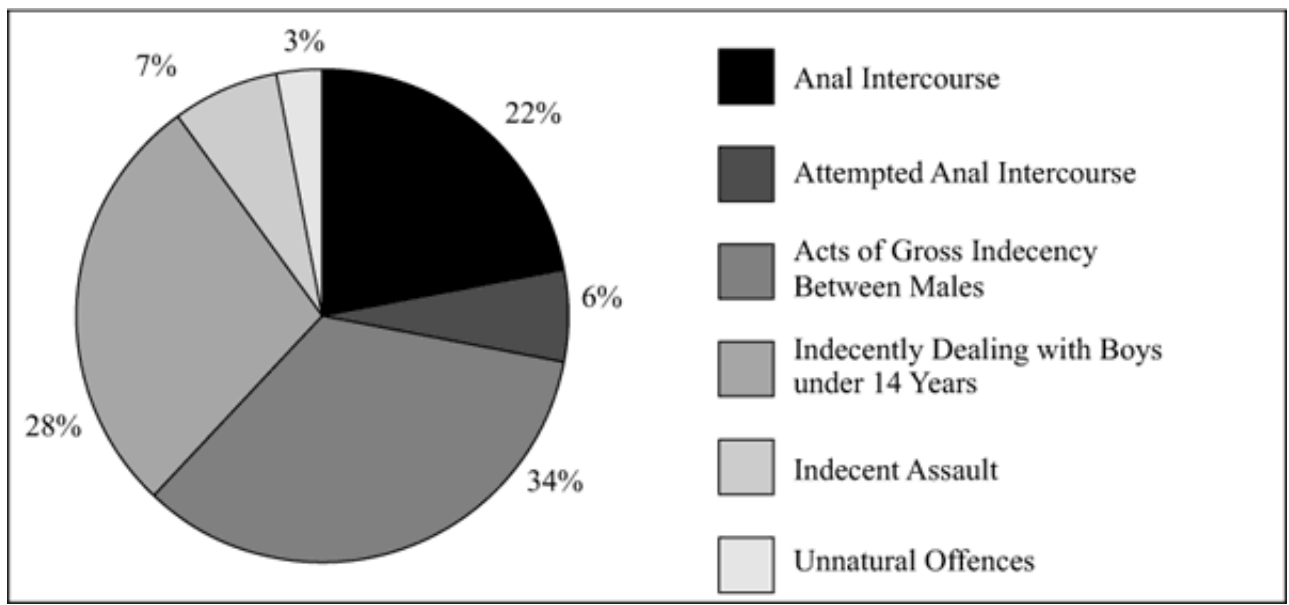

The anal intercourse convictions are markedly higher in the colonial period (54\%) than during the twentieth century (22\%) (Charts Three and Four). The categories available for charges between 1860 and 1900 were much simpler than in the later period: there are only two charges, anal intercourse and attempted anal intercourse (46\%). The difference in percentages is not extreme, particularly when compared with the same division between 1901 and 1954, which shows quite marked differences between 
convictions for the same two charges. Chart Four (1901-1954) shows the expanded range of charges possible under the 1899 Act. Of the total convictions after 1901, only $22 \%$ were for anal intercourse, and $6 \%$ were for attempted anal intercourse. The most likely explanation for this is that, until the 1899 Act added extra categories, the same categories had been subsumed in "attempted buggery" charges under the 1865 Act, or, following the English pattern mentioned above, were dealt with as misdemeanours. A new charge was introduced with the 1899 Act, namely, "Indecent Practices between Males" (the 1885 Labouchere amendment), which became the most deployed of all charges in the twentieth century, accounting for $34 \%$ of convictions. Little chance of acquittal followed trial, and the conviction rate rose onwards from 1941. As with "Indecent Practices between Males", the Section entitled "Indecent Treatment of Boys under Fourteen" was a feature of the 1899 Act, accounting for 28\% of all convictions up to 1954. After "Indecent Practices between Males", anal intercourse was the next most used charge, and offenders faced a high probability of being found guilty if taken to trial. There is also a minor category in Chart Four that we have labeled "Unnatural Offences". Section 208 of the Act, dealing with anal intercourse, is headed "Unnatural Offences". Three percent of the offences with sentences recorded were listed only as "Unnatural Offences". Although these cases probably involved anal intercourse, we chose to list them separately. It seems probable that this $3 \%$ should be added to the anal intercourse percentage and that the figure was really closer to $25 \%$.

The divorce of bestiality from male-to-male anal intercourse is indicative of the end of old definitions of sodomy that extended to all forms of non-procreative sexual activity, including sex with animals. The diversification of categories and sentences under Griffith's 1899 Act indicates an increased understanding of the physical nature of male homosexuality. The data also shows that, particularly by the 1940 s and early 1950 s, a number of the men found guilty no longer received prison sentences. Over the first forty years of the twentieth century, $4 \%$ of sentences were either suspended or a monetary fine was imposed, whereas between 1941 and 1954 the number of sentences not involving imprisonment rose to $24 \%$, mostly juvenile offenders. Male-to-male sexual activity gradually became understood as a sexual identity, with strong condemnation reserved only for adult males involved with minors ${ }^{30}$.

The "Indecent Assault" category was also available to police charging male-to-male sexual offences, but in the archival files these charges are conflated with heterosexual charges, and although we have calculated this category as $7 \%$ of the total charges, the number was possibly even higher. Deployment of a wider range of charges during the twentieth century cuts two ways: police were more likely to ensure a conviction, but this also usually resulted in a lower level sentence.At a legislative level, a comparison of the two Acts reveals a 'softening' of the sentence for male-to-male sexual activity. The reduction in the permissible maximum sentence is evidence of an increasingly 'tolerant' attitude by the legal arm of the government, and perhaps acknowledgement of relaxation of broader community opinion, except when it came to sex with boys. The new concentration on youthful offenders is also an indication of interest in child protection, which became more pronounced through government and community institutions as the twentieth century progressed ${ }^{31}$. 


\section{Male-To-Male Anal Intercourse}

Section 62 of the 1865 Act dealt with "the abominable crime of buggery" and allowed for a sentence of between ten years and life imprisonment ${ }^{32}$. The maximum sentence under the equivalent clause in the 1899 Act was reduced to "imprisonment with hard labour for fourteen years" ${ }^{33}$. As already noted, there was a marked decline in prosecutions for this offence, particularly in the post-Federation decades. If brought to trial, the defendant had only a $25 \%$ chance of being found guilty during the nineteenth century (Chart Five) $)^{34}$. The chance of acquittal was much less during the first half of the twentieth century, when $74 \%$ of those charged were found guilty (Chart Six) ${ }^{35}$. During the 1930s, the accused had a $60 \%$ chance of being found guilty. Guilty verdicts reached their highest point $(91 \%)$ in the 1940s, falling to $81 \%$ during 1951-1954 at the end of the years under investigation.

Chart Five: Verdicts, Queensland Courts: For the Offence of Anal Intercourse 1860-1900

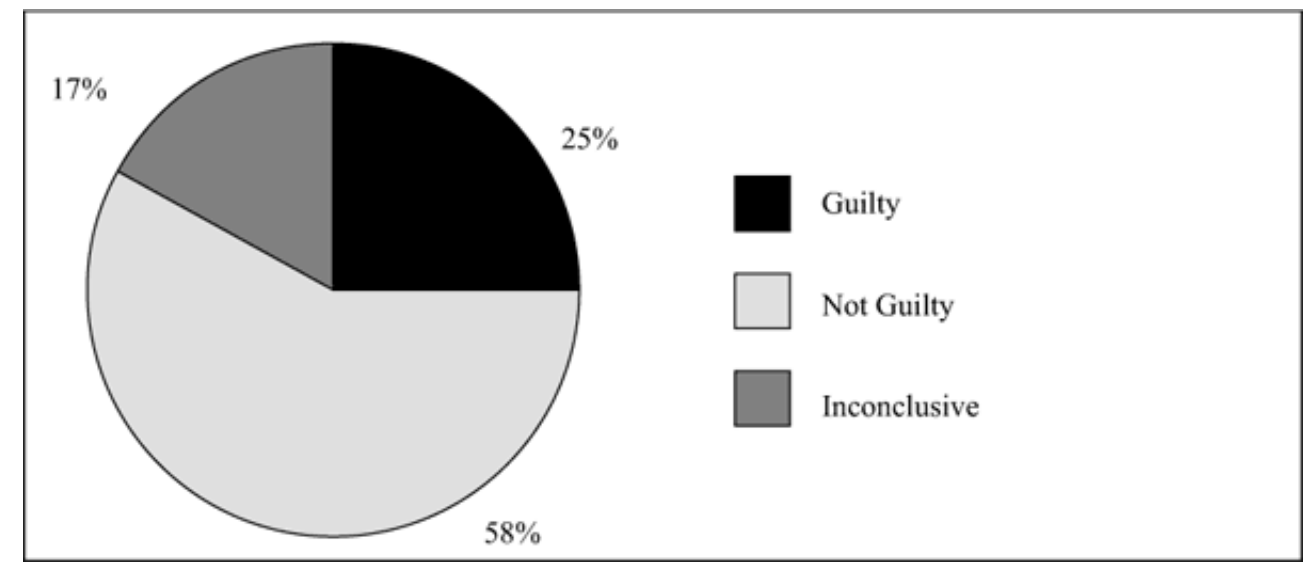

Chart Six: Verdicts, Queensland Courts: The Offence of Anal Intercourse 1901-1954

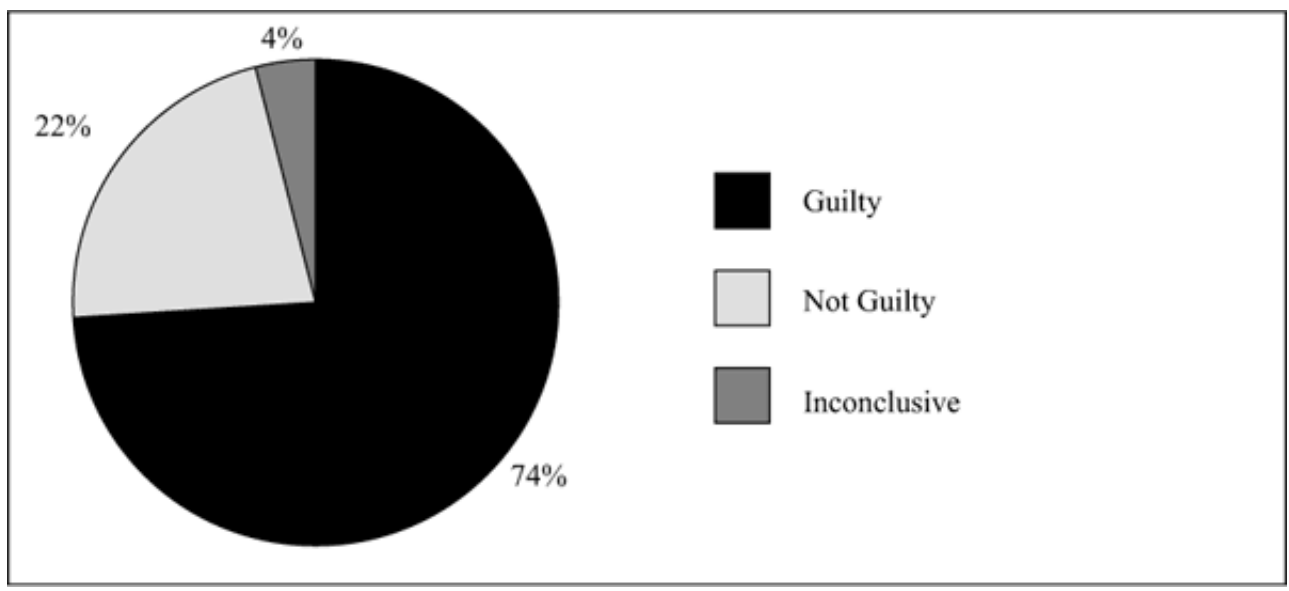

\section{Severity of Sentence}

In the colonial years, given the severity of the possible sentence, courts were careful in their investigations, finding insufficient evidence to convict in $58 \%$ of cases, and the mean sentence passed was eight years imprisonment, with twenty years the maximum 
awarded only once, in $1875^{36}$. The leniency factor was probably even higher if we take into account that at least half of the inconclusive cases (where no verdicts have been located) probably involved a not guilty verdict. Judges obviously had the discretion to impose lighter sentences than the Acts specified ${ }^{37}$.

In the post-Federation years the judiciary also passed relatively lenient sentences, but rare was the sentence that did not allot hard labour to accompany the prison term, if the offender was the active partner and an adult. The average sentence was three years, accompanied by hard labour, the latter used as a multiplication factor in the severity of any sentence. Although three years with hard labour was well below the possible upper sentence, it was still a severe sentence. There was a marked decline in prosecutions for this offence during the post-Federation period, although the probability of being convicted was much greater than in the colonial period and a definite trend can be discerned here, particularly onwards from the 1930s, when there was a high probability of receiving a guilty verdict.

\section{Age of Offender}

No comprehensive age data is available for the colonial period, but youths under fifteen are involved in about eight (8.8\%) of the 90 cases. Colonial Queensland was an overtly male frontier society, with limited access to female company. Men married late and a surprising number never married ${ }^{38}$. As argued in the introduction, in the nineteenth century a transition was occurring between earlier gender and sexual systems where youths were available to be penetrated sexually by adult males, with no loss of gender status to either. This pattern probably survived longest in rural European and British working-class culture, as well as in settler colonies such as those in North America and Australia. Separate social spheres for male and females ensured that males of all ages remained in closer touch with each other than with women ${ }^{39}$. Adult propositioning of youths was not unusual, particularly in employment situations. From a reading of the court cases it seems that some youths were very willing participants, and that, when adults shared sleeping quarters with youths, sexual activity was a possible outcome. Sentences were more severe when the boys involved were under fourteen years.

Chart Seven: Queensland Courts: Age of Persons found Guilty of Anal Intercourse 1901-1954

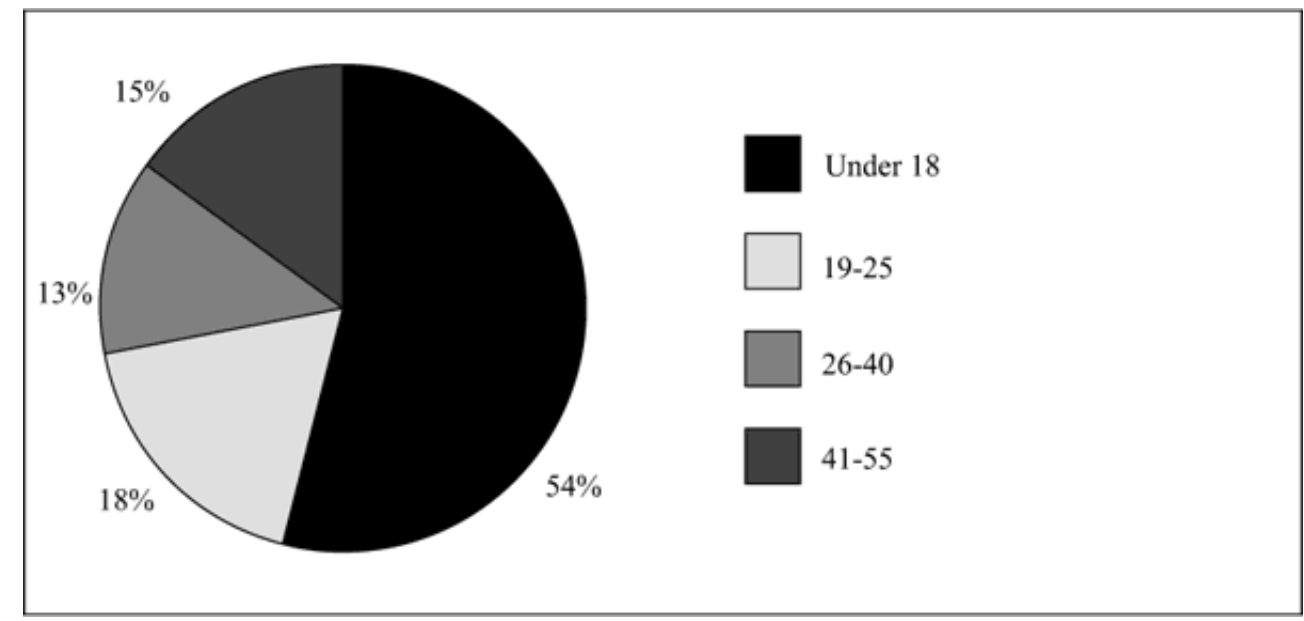


What is striking for the post-Federation period (Chart Seven) is the marked tendency for this to be the preferred charge against youths and young adult males. In cases where a guilty verdict was passed, the great majority involved those in the under-26 age-group, amounting to $72 \%$ of the total. There was a marked leniency in sentencing when the defendant was a minor, defined legally as a male under 21 years of age. Minors constituted well over $60 \%$ of total cases in which guilty verdicts were delivered. Only $17 \%$ of minors received a prison sentence, at a mean of two years with hard labour. Alternative sentences were by far the most common form of punishment. Fines amounted to $33 \%$ of sentences, followed by committal into state care (25\%), probation (17\%) and release under their own recognizances (8\%). It seems probable that the courts recognized that homosexual activity, while still not acceptable, was no longer considered an abomination and should be treated with compassion; and that youthful experimentation should not be allowed to ruin adulthood. Eighteen percent of those convicted for anal intercourse were between 19 and 25, 13\% between 26 and 40, and $15 \%$ between 41 and 55 years of age. Passage into adulthood saw a sharp rise in the severity of sentencing. Eighty-five percent of those found guilty were over eighteen years old and received prison sentences at a mean of four years hard labour, which was well below the possible maximum ${ }^{40}$.

\section{Attempted Male-To-Male Anal Intercourse}

The lesser crime ofattempted male-to-male anal intercourse is a category in both the $1865^{41}$ and 1899 Acts ${ }^{42}$. What seems obvious from the case reports is that when penetration could not be proved, or perhaps when the couple had no intention of having penetrative sex, the police resorted to this secondary charge, for which they were more likely to gain a conviction. Charts Eight and Nine show that there was a very substantial chance that this charge would ensure a conviction: 61\% from 1860 to 1900 and 67\% from 1901 until 1954.

Attempted male-to-male intercourse constituted $46 \%$ of total prosecutions during the colonial period (Chart Three). The chances of being found guilty were much greater (61\% - Chart Eight) than for the charge of male-to-male intercourse $(25 \%$ - Chart Five ${ }^{43}$. Again, probably reflecting the increased differentiation in charges evident in the 1899 Act, attempted male-to-male intercourse comprised only 6\% of total prosecutions in the post-Federation period (Chart Four). As expressed in Chart Nine, following the pattern previously outlined for male-to-male intercourse, during the first half of the twentieth century the conviction rate was high, with $67 \%$ receiving a guilty verdict, and $29 \%$ a not-guilty verdict ${ }^{44}$.

\section{Severity of Sentence}

As with male-to-male intercourse, sentencing was relatively lenient, heavier sentences reserved for adults involved with youths or young boys. Between 1860 and 1900, the sentences range from eighteen months to five years, with a mean sentence of four years imprisonment without hard labour, or one year with hard labour. 
Chart Eight: Verdicts Queensland Courts: Offence of Attempted Anal Intercourse 1860-1900

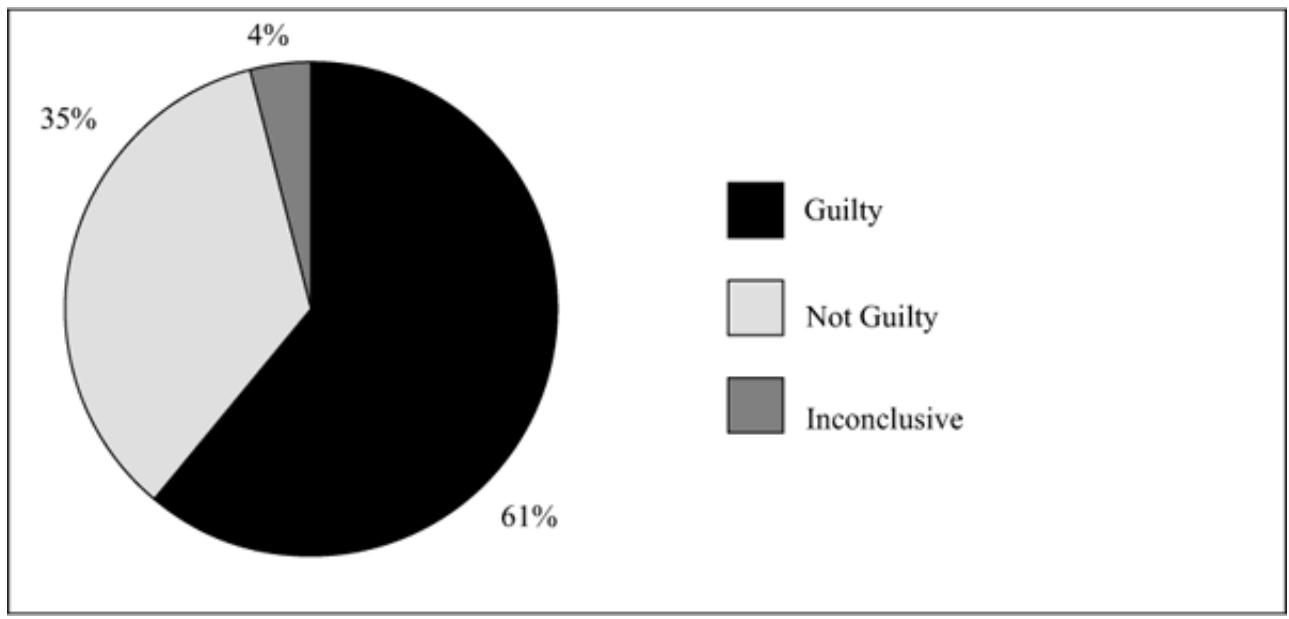

Chart Nine: Verdicts Queensland Courts: Offence of Attempted Anal Intercourse 1901-1954

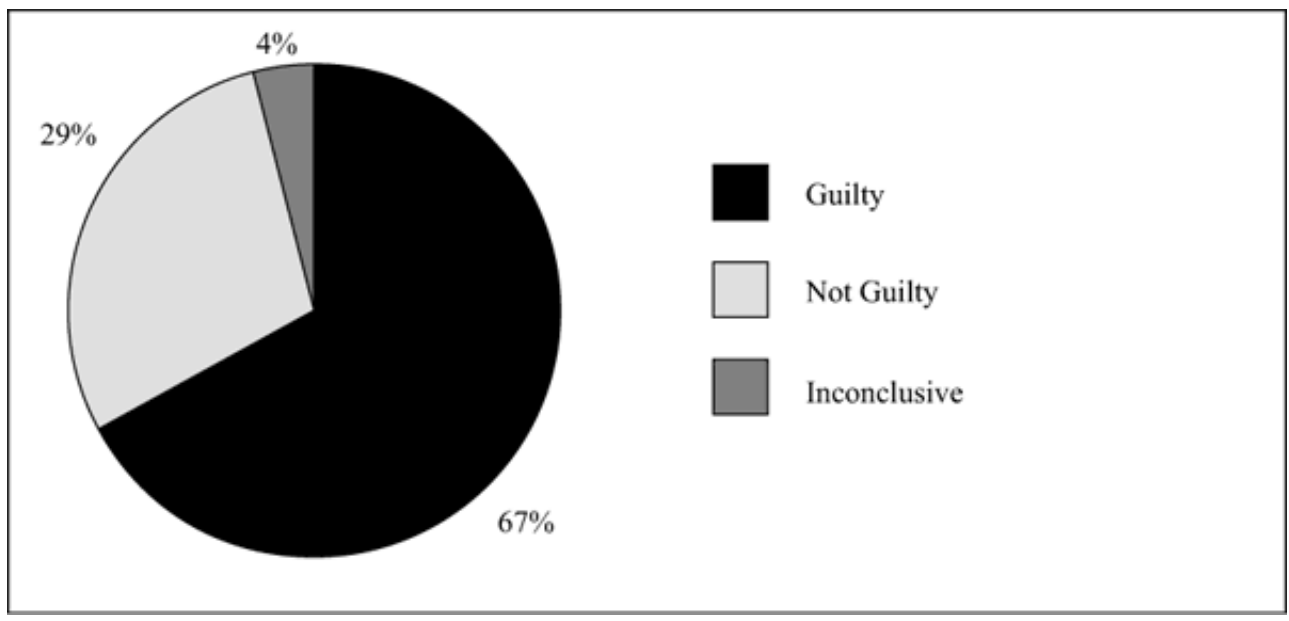

Over the next fifty years (when this category is only $6 \%$ of the total convictions) the sentences are much lighter, although often the "attempt" is coupled with another charge, such as "Indecent Practices between Males".

\section{Age of Offender}

Again, no statistics are available for the pre-1901 years, but as Chart Ten shows, interestingly, during the 1901-1954 years no charges for this offence were brought against individuals who were under twenty-six years old. The main concentrations are in the 26-35 (40\%) and 41-55 (40\%) age groupings, although the $20 \%$ who were over 55 years of age are also quite significant in the total figure. Why were no males under twenty-five ever convicted for this offence? The glaring difference between these statistics and those in the previous category ( $72 \%$ of those convicted for committing anal intercourse during the same period were under 26 years of age - Chart Seven), requires some attempt at explanation. At least forty of the more than 400 charges during the first half of the twentieth century involved Beats, and others could be construed as related to the development of early gay social world sites such as boarding houses, hotels, coffee shops and movie theatres. The half-century time span also 
includes the Second World War - years of increased sexual promiscuity - and the rightwing backlash that followed, which are proportionally over-represented in the cases. We do not know what advice desk sergeants were giving to young constables on how to proceed with charges, but it seems feasible to argue that this more easily proved charge - the attempt, stopping short of penetration - was used as a social control mechanism by police trying to retard the development of the growing urban adult gay subculture, particularly in Brisbane and regional centres.

Chart Ten: Queensland Courts: Age of Persons found Guilty of Attempted Anal Intercourse 1901-1954

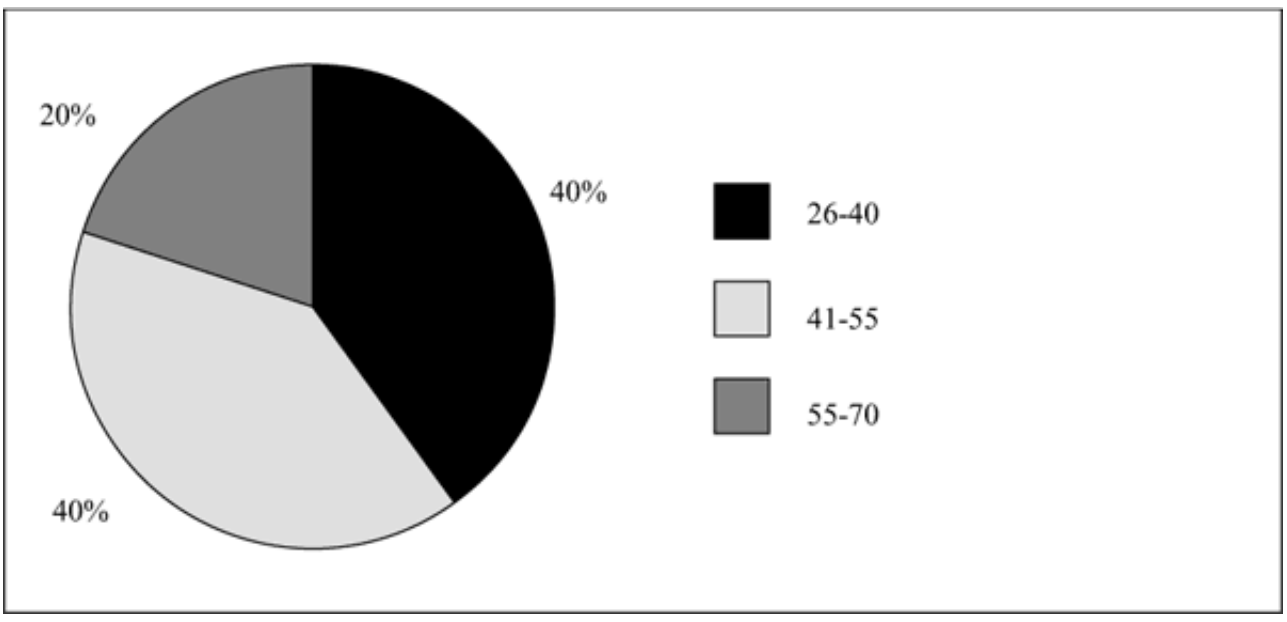

\section{Indecent Practices Between Males}

\section{Overall offence findings}

The misdemeanour of "Indecent Practices between Males" - mutual masturbation, fellatio and other forms of non-penetrative sexual acts - came into legislative being through the $1899 \mathrm{Act}^{45}$. As Chart Four reveals, the charge made up 34\% of convictions during the first half of the twentieth century, and was the most deployed of all the charges brought against those accused of male-to-male sexual activity. 


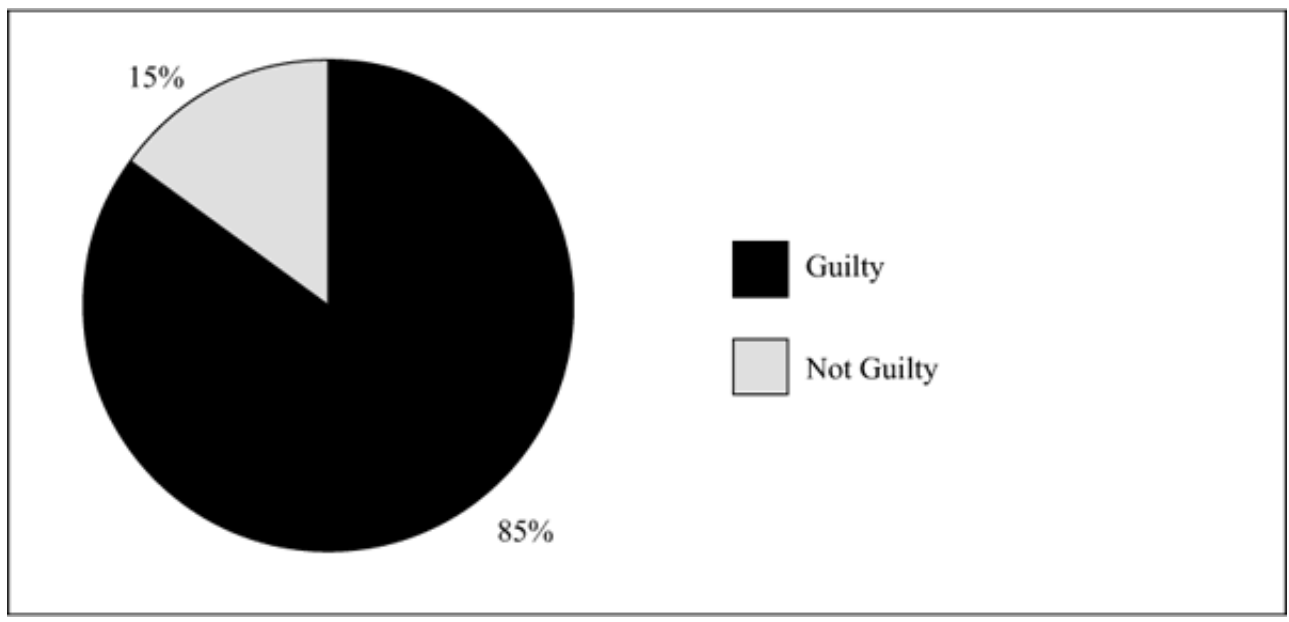

Chart Twelve: Queensland Courts: Age of Persons found Guilty of Gross Indecency between Males 1901-1954

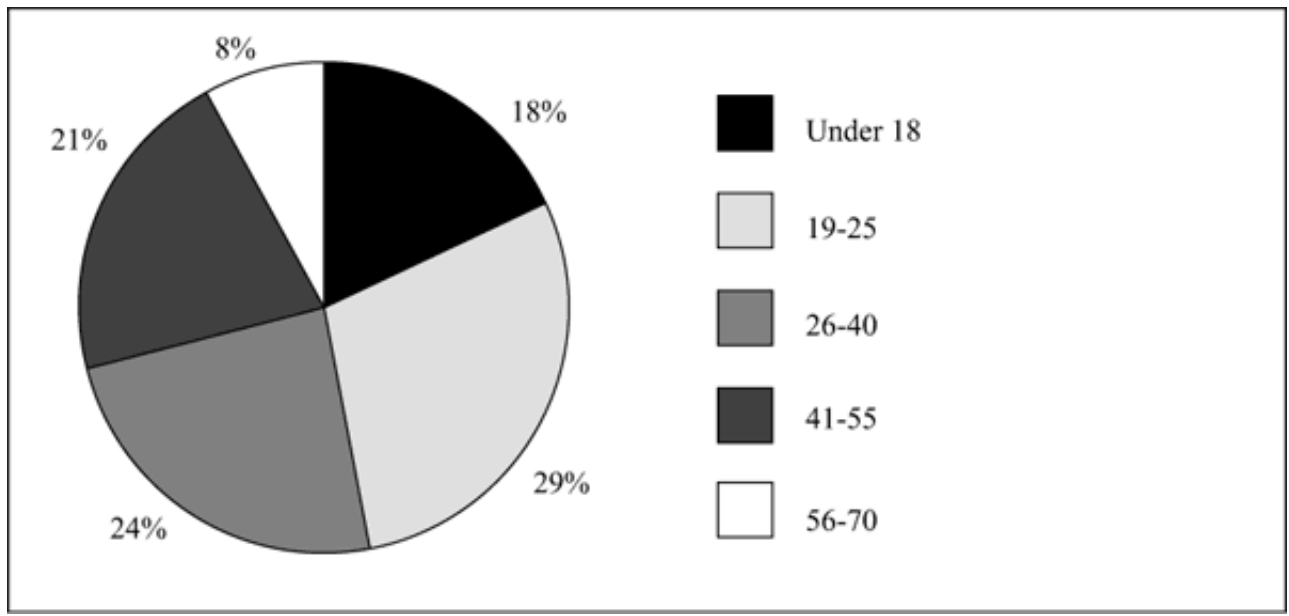

Further, the offender stood little chance of acquittal, with a high conviction rate. The police often viewed the charge of "Indecent Practices between Males" as the most appropriate for punishing homosexual activity, given that it was a misdemeanour, the sentence range was lower, and proof did not involve medical examinations. There can also be no doubt that this charge was mostly used to limit sexual activity in public places, and to control what Moore has argued to be the public face of the growing gay subculture ${ }^{46}$.

\section{Severity of Sentence}

Between 1901 and 1954, 85\% of males charged with this offence were found guilty (Chart Eleven). Although the sentence could bring up to three years in prison with hard labour, it was dealt with relatively leniently, and similarly to attempted anal intercourse charges, the "Indecent Practices between Males" charge was used by the police as a convenient way to gain a conviction, even when a more severe charge could have been laid. It is discernible from 1931 onwards that the courts also increasingly adopted alternatives to imprisonment as the most usual mode of punishment, judges 
awarding suspended sentences. Sentences varied between one month and two years, usually with hard labour, but as early as 1910 a suspended sentence with a bond was used. It is clear that, onwards from the early 1930s, the courts also increasingly began to impose non-prison sentences on those found guilty of this misdemeanour. Seventeen percent of offenders were fined, $21 \%$ received suspended sentences, $8 \%$ were placed on probation, and $9 \%$ were released on their own recognizances.

\section{Age of Offender}

41 The age pattern of convictions for "Indecent Practices between Males" from 1901 to 1954 (Chart Twelve) shows youths and young men to be highly represented as offenders. Eighteen percent were under eighteen years, and a further $29 \%$ were under twenty-five years, which means almost half were under twenty-six years old. Then, the mean number of prosecutions declines, to $8 \%$ for the 26-50 age group and to $3 \%$ for the over fifties. Imprisonment shows a strong correlation with age, as, the younger the offender, the greater the prospect of a non-custodial sentence. No prison sentences were passed on the under thirties, whereas $90 \%$ of cases involved men over thirty years of age, who received a mean sentence of two years hard labour. In line with developments outlined earlier, the criminal justice system increasingly imposed nonprison sentences on younger offenders. To return for a moment to the explanation of the data on the age of offenders convicted of attempted male-to-male intercourse, perhaps police were deliberately lowering the severity of the charge to that of a misdemeanour for teenagers and men in their early twenties, as revealed in Chart Twelve.

\section{Indecent Treatment of Boys Under Fourteen}

Stephen Angelides (2005) suggests that as homosexuality became normalised in late twentieth century discourse, male paedophilia became the new deviant category. The court records suggest that this new pattern has been building for many decades. Although there was no equivalent category during the nineteenth century, a check of the court cases reveals fifteen out of ninety cases (16\%) appear to involve boys under fourteen. This charge, as with the one just considered, was introduced with the 1899 Act $^{47}$. Other than "Indecent Practices between Males", this offence was the most prosecuted, covering 28\% of all convictions in the period 1901 to 1954 (Chart Four). 
Chart Thirteen: Verdicts, Queensland Courts: Offence of Indecently Dealing with a Boy under Fourteen 1901-1954

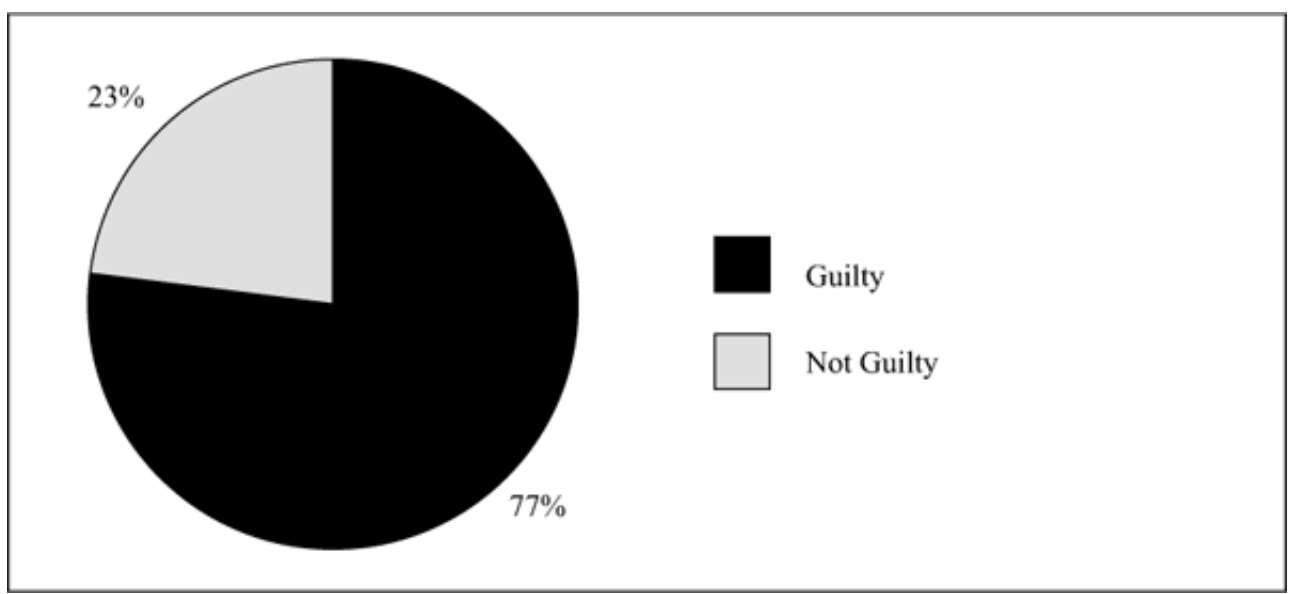

Chart Fourteen: Queensland Courts: Age of Persons found Guilty of Indecently Dealing with a Boy under Fourteen 1901-1954

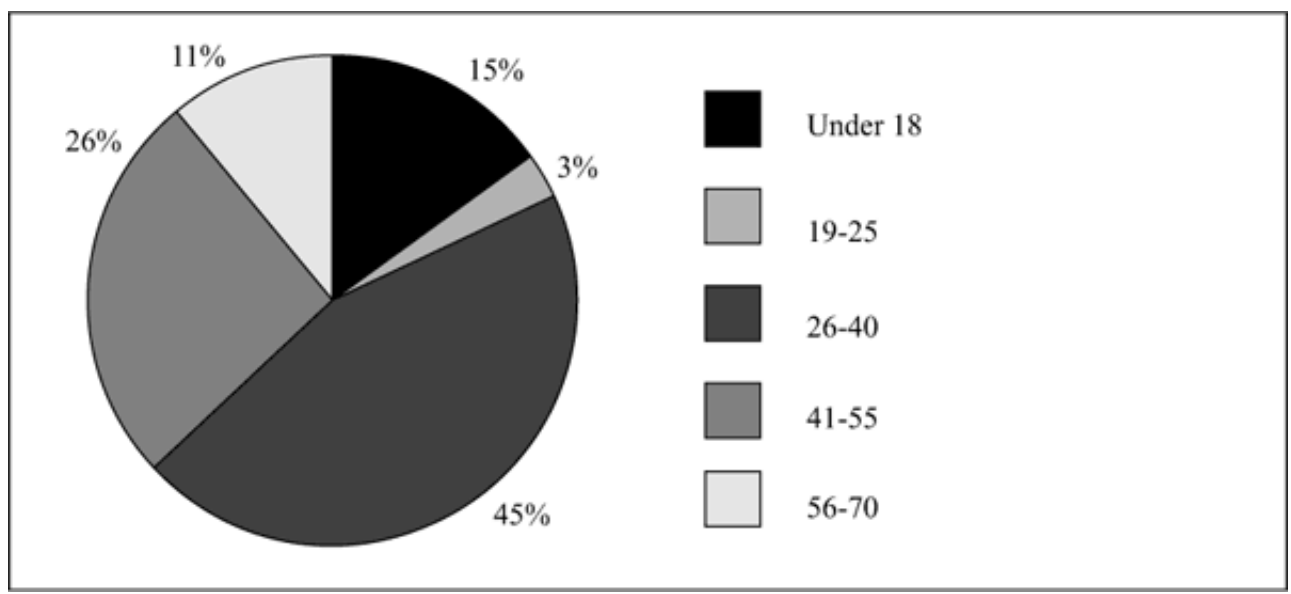

Chart Thirteen shows that in $77 \%$ of cases the defendant was found guilty. Little variation was detected over the years under discussion, although the conviction rate climbs quite steeply, from $80 \%$ in the 1920 s, to $92 \%$ in the first half of the 1950 s.

These cases were often more obvious that those between adults. Youths were less able to maintain privacy and adults were inclined to report incidents of under-age sexual activity to the police. But rather than indicating that paedophilia was rampant in Queensland, it shows community and judicial concern to safeguard the rights of minors, as well as the slow creation of this new deviant category.

\section{Severity of Sentence}

In line with developments mentioned above, during the twentieth century judges were relatively lenient in their sentencing. Particularly if the person charged was a minor, he was likely to receive a non-custodial sentence. The possible maximum sentence of seven years with hard labour was never even remotely approached, although judges invariably ordered lesser prison sentences with hard labour if guilt was established. The mean sentence was two years with hard labour, and the maximum sentence awarded was three years with hard labour. If the offender were under eighteen years of 
age, leniency could be expected with only a $20 \%$ chance of imprisonment. Forty percent received a suspended sentence, $20 \%$ had to pay a fine, and $20 \%$ were released under their own recognizance.

\section{Age of Offender} pre-pubescent boys. As illustrated in Chart Fourteen, 15\% of those convicted were under eighteen years old, which indicates that in a reasonably large proportion of the cases the two partners were adolescents, with only a few years difference between their ages. An almost irrelevant 3\% of the charges involve young men aged between nineteen and twenty-five, suggesting perhaps that this age group had other sources of sexual outlet because they had easier access to female partners. Most of those convicted under this charge were middle-aged. Eighty-two percent of the offenders were over twentyfive years old: $45 \%$ were between twenty-six and forty; $26 \%$ were between forty-one and fifty-five, and $11 \%$ were between fifty-six and seventy years old.

\section{Judges and Juries}

Nothing of interest was discovered through examining the sentences handed down by individual judges. There was little variation in sentencing in regard to age, or severity of sentence, and the law was administered in a uniform manner. Some of the judges' notebooks are available, but there is nothing of particular interest in them in relation to these cases. Jury lists are sometimes available, but we have not attempted to analyse the type of jurors chosen. There is also nothing in the records to indicate any advice given by judges, such as recommendations to juries on the nature of charges, interpretation and admissibility of evidence and issues of culpability. For the period before the 1865 Act, when capital punishment was the mandatory sentence, the findings of Barber and Sturma suggest that juries were unwilling to convict because of the possible severity of the outcome. Sturma also makes some points that are probably valid for most of the period under review. Witnesses were reluctant to appear in cases involving homosexuality, 'victims' were reluctant to give evidence, and newspapers suppressed details of 'unnatural offences'. There was always an element of impropriety in these cases that made them unusual ${ }^{48}$. However, even in the nineteenth century, there is an indication that these 'crimes' were not thought to be as much of an abomination as is often suggested, and clearly, the sentences specified in the Acts were considered to be too excessive. Certainly, it seems that judges during the first half of the twentieth century felt that non-custodial sentences were acceptable forms of punishment.

\section{Conclusion}

The findings of this research are sometimes surprising, and raise questions that are not always easy to answer. Comparison between homosexual offences and any other categories of criminal offences is difficult and not terribly rewarding ${ }^{49}$. One of the most unexpected conclusions of this study is that the full severity of the law was seldom enforced, but as noted earlier in this paper, as far back as the 1840s and 1850s sodomy

Crime, Histoire \& Sociétés / Crime, History \& Societies, Vol. 11, $\mathrm{n}^{\circ} 1$ | 2007 
sentences were usually lower than the minimum specified in law. Despite the constant invective about "abomination", the judges' sentences were moderate, within the possible range of severity. The only conviction that always received a heavy punishment was for paedophilia, and generally there is a pattern of obvious bias against older offenders in all categories. The role played by the use of No True Bill and Nolli Prosqeui decisions is not clear, but presumably there was a great deal of behindthe-scenes bargaining to have cases processed using these procedures, as well as genuine police decisions that there was not enough evidence to proceed. Charges seem sometimes to have been laid to frighten and intimidate men who were probably involved in homosexual activity, even when the police realised that they could never secure a conviction. Actually proving anal penetration had occurred was very difficult, even with an eye-witness to the event, or subsequent medical examination, which indicates that the police probably often perjured themselves and the courts accepted their shoddy evidence. The police seem to have chosen their charges carefully and have targeted certain groups with particular charges, which in the twentieth century probably relates to attempts at policing the growing homosexual subculture.

There is no indication that the laws were used more severely against non-Europeans. There are around ten cases of prosecutions of Asians during the colonial period, but they also received No True Bill and Nolli Prosqeui decisions and sentences are no higher than for other offenders. Particularly in the nineteenth century, there are short spates of cases involving Asians and Melanesians, which seem to relate to local or individual agendas and soon pass. No Asians appear in the records after 1944, and Australian Aborigines appear only twice, once as a witness in 1894, and the other as an underage partner in $1906^{50}$.

It is unclear why the Labouchere amendment was deliberately removed from Queensland's 1891 version of the British 1885 Act, but included in the 1899 Act, nor why it was introduced decades later in other Australian jurisdictions. Griffith's 1899 Act divided male-to-male sexual activity into several categories, which although they still carried severe sentences, showed that he was aware of the diverse nature of the physical side of male sexuality. But he continued to link homosexuality and bestiality in his revised legislation, which shows that his thinking was not truly modern. Griffith was a thorough, thoughtful man, a great jurist, and presumably would have been alarmed if he had know that his 1890s revision of the law in regard to homosexuality largely stayed in place until 1990, even though, as with the 1865 legislation, judges exercised leniency in their sentencing.

David Halperin suggests that there were four pre-homosexual categories of male sex and sexual deviance which we can discern as discourses: effeminacy; pederasty or 'active' sodomy; friendship or male love; and passivity or inversion. In earlier discourse, only one of the partners is referred to - the 'active' partner in sodomy and the effeminate male or masculine female in cases of 'inversion'. The term 'homosexual' applies to both partners, whether active or passive, and to quote Halperin, homosexuality "implies that same-sex sexual feeling and expression, in all their many forms, constitute a single thing, called 'homosexuality', which can be thought of as a single integrated phenomenon, distinct and separate from "heterosexuality" 51 . Once homosexuality became established as both a concept and a social practice, Halperin and others argue that erotic organisation is reorganised and gender and gender roles lose significance for categorising sexual acts. Sexual object choice becomes detached from 
gender identity and man and women can be 'homosexual' while maintaining normative behaviour.

At the beginning of this article, we sketched out the way that historians believe the homosexual subculture developed historically, from its probable origins in the eighteenth century Mollie houses, into a gay urban scene onwards from the 1890 s. Brisbane had a discernable middle class same-sex community in the 1920s and 1930s, which held house parties and occasionally drew unwanted attention from the more scurrilous parts of the media ${ }^{52}$. While this was embryonic compared with Chauncey's "gay world" of New York in the 1930s, the timing mirrors the American urban pattern. During the Second World War, Queensland became a major Allied base, causing largescale social disruption, which, in the same way as occurred in the USA, inadvertently furthered the development of what became a flourishing gay and lesbian scene ${ }^{53}$. Brisbane and several other coastal cities became military garrison towns, promoting sexual liberation and excesses of all types. After the war and in early Cold War years, forces of repression were unleashed, partly as a local attempt to return Queensland to a more 'moral' society but also as part of international forces, which served to inhibit public expression of the gay subculture ${ }^{54}$. At the same time, overwhelming demographic, medical and legal changes were moving towards creating a more liberal society. Initially allied to the bohemian subculture, the camp (the common 1950s-60s Australian word for gay) subculture began to draw apart, developing a separate social scene, although this did not become politicised until the $1970 \mathrm{~s}^{55}$.

During the period in which a homosexual subculture developed in Queensland, medical and legal experts were developing a better understanding of homosexuality, and society slowly moved towards an acceptance of different sexual values and desires. There is also an acknowledgement through the courts that sentencing should be compassionate, at the lower end of the scale, and increasingly involve suspended sentences and monetary punishments. Chauncey argues that hetereo-homosexual binarism is a relatively recent development, and that in New York it dates from the middle of the twentieth century ${ }^{56}$.Earlier, there were clearly 'inverted' effeminate men, and men who involved themselves in same-sex activities without necessarily being part of a subculture. In Queensland, the development of male homosexuals who maintain normative appearances but were identifiable as part of the subculture, does not occur until the 1960s and 1970s. The time difference is to be expected: Queensland was largely rural, the state had a conservative repressive government, and until the 1970s Brisbane, the capital, was often described as a large country town.

Acceptance of homosexuality and acknowledgement of a subculture by the general public was much slower than acknowledgement by legal and medical authorities. Conservative politicians, right-wing Christians and sections of the media maintained a reactionary moral stand through public rhetoric right up until de-criminalisation occurred in 1990; and indeed beyond until the present-day. Like so many other aspects of the justice system when it touches on individual choice - for instance, the possession of marijuana, or prostitution and abortion - the letter of the law was not always fully observed, even in situations when 'abominable' acts are supposed to be against the moral orthodoxy of the majority. 


\section{Acknowlegdements}

55 We are indebted to Mark Finnane of Griffith University and Anthony Yeates of University of Queensland, and to barrister Richard Galloway for their assistance, and to the two anonymous reviewers for their comments.

\section{BIBLIOGRAPHY}

Aldrich R. (Ed.), 1993, Gay Perspectives II: More Essays in Australian Gay Culture, Sydney, Department of Economic History and the Australian Centre for Gay and Lesbian Research, University of Sydney.

Aldrich R., 2003, Colonialism and Sexuality, London, New York, Routledge.

Angelides S., The Emergence of the Paedophile in the Late Twentieth Century, Australian Historical Studies, 2005, 36, 126, pp. 272-295.

Barber R., Capital Punishment in Queensland, BA Hons, Thesis, Department of Government, University of Queensland, 1967.

Baskerville B., “Agreed To Without Debate": Silencing Sodomy in 'Colonial' Western Australia, 1870-1905, in Aldrich R., Wotherspoon G. (Eds), Gay and Lesbian Perspectives IV: Studies in Australian Culture, Sydney, Department of Economic History with the Australian Centre for Gay and Lesbian Research, University of Sydney, 1998, pp. 95-115.

Bavin-Mizzi J., “An Unnatural Offence”: Sodomy in Western Australia from 1880 to 1900, in Fox C. (Ed.), Studies in Western Australian History, XIV, Perth, Centre for Western Australian History, University of Western Australia, 1993, pp. 102-120.

Berube A., Marching to a Different Drummer: Lesbian and Gay GIs in World War II, in Snitow A., Stansell C., Thompson S.(Eds), Powers of Desire: The Politics of Sexuality, New York Monthly Review Press, 1983, pp. 88-99.

Berube A., Coming Out Under Fire: The History of Gay Men and Women in World War II, New York, Free Press, 1990.

Bleys R. C., The Geography of Perversion: Male-to-Male Sexual Behaviour Outside the West and the Ethnographic Imagination, 1750-1918, New York, New York Press, 1995.

Carr A., Policing the "Abominable Crime" in Nineteenth Century Victoria, in Phillips D.L., Willett G. (Eds), Australia's Homosexual Histories: Gay and Lesbian Perspectives V, Sydney and Melbourne, Australian Centre for Lesbian and Gay Research and the Australian Lesbian and Gay Archives, 2000), pp. 27-40.

Chauncey G., Gay New York: Gender, Urban Culture, and the Making of the Gay Male World, 1890-1940, New York, Basic Books, 1994.

Collins A.-M., Woman or Beast? Bestiality in Queensland, 1870-1949, Hecate, 1991a, 17, 1, pp. 36-42. 
Collins A.-M., Testimonies of Sex: Rape in Queensland, 1880-1919, Journal of Australian Studies, 1991b, 29, pp. 50-63.

Connors L., Two Opposed Traditions: Male Popular Culture and the Criminal Justice System in Queensland, in Aldrich R. (Ed.), Gay Perspectives II: More Essays in Australian Gay Culture, Sydney, Department of Economic History, University of Sydney, 1993, pp. 83-114.

D’Emilio J., Freedman E. B., Intimate Matters: A History of Sexuality in America, New York, Harper \& Row, 1988.

Emsley C., Crime and Society in England, 1750-1900, London \& New York, Longman, $2^{\text {nd }}$ edition, 1996.

Faro C., Wotherspoon G., Street Seen: A History of Oxford Street, Carlton South (Vic.), Melbourne University Press, 2000.

Finnane M., Punishment in Australian Society, Melbourne, Oxford University Press, 1997.

Finnane M., Garton S., The Work of Policing: Social Relations and the Criminal Justice System in Queensland, 1880-1914, Part I, Labour History, 1992a, 62, pp. 52-70.

Finnane M., Garton S., The Work of Policing: Social Relations and the Criminal Justice System in Queensland, 1880-1914, Part II, Labour History, 1992b, 63, pp. 43-64.

Fletcher A., Gender,Sex and Subordination in England, 1500-1800, New Haven, Yale University Press, 1995.

Fogarty W. J., "Certain Habits": The Development of a Concept of the Male Homosexual in New South Wales Law, 1788-1900, in Aldrich R., Wotherspoon G. (Eds), Gay Perspectives: Essays in Australian Gay Culture, Sydney, Department of Economic History, University of Sydney, 1992, pp. 59-76.

Freiberg A., Ross S., Sentencing Reform And Penal Change: The Victorian Experience, Sydney, Federation Press, 1999.

Gilbert A. N., Buggery and the British Navy, 1700-1861, Journal of Social History, 1976, 10, 1, pp. 72-98.

Goldman L., Child Welfare in Nineteenth Century Queensland, 1865-1911, MQual Thesis, Department of History, University of Queensland, 1978.

Halperin D.M., How to Do the History of Male Homosexuality, GLQ: A Journal of Lesbian and Gay Studies, 2000, 6, 1, pp. 87-124.

Harvey A.D., Prosecutions for Sodomy in England at the Beginning of the Nineteenth Century, The Historical Journal, 1978, 21, pp. 939-948.

Hekma G., Amsterdam, in Higgs D., (Ed.), Queer Sites: Gay Urban Histories since 1600, London and New York, Routledge, 1999, pp. 61-88.

Hughes R., The Fatal Shore, London, Collins/Harvall, 1987.

Ingram G. B., Returning to the Scene of the Crime: Uses of Trial Dossiers on Consensual Male Homosexuality for Urban Research, with Examples from Twentieth-Century British Columbia, GLQ: A Journal of Lesbian and Gay Studies, 2003, 10, 1, pp. 77-110.

Joyce R. B., Samuel Walker Griffith, St Lucia (Qld), University of Queensland Press, 1984.

Kennedy E. L., Davis M.D., Boots of Leather, Slippers of Gold: The History of a Lesbian Community, New York, Routledge, 1993. 
McLachlan N., Waiting for the Revolution: A History of Australian Nationalism, Ringwood (Vic.), Penguin, 1989.

Meer van der T., The Persecutions of Sodomites in Eighteenth-Century Amsterdam: Changing Perceptions of Sodomy, in Gerard K., Hekma G. (Eds), The Pursuit of Sodomy: Male Homosexuality in Renaissance and Enlightenment Europe, New York, Harrington Park Press, 1989, pp. 263-307.

Moore C., That Abominable Crime: First Steps in the Social History of Male Homosexuals in Colonial Queensland, 1859-1900, in Aldrich R. (Ed.), Gay Perspectives II: More Essays in Australian Gay Culture, Sydney, Department of Economic History with the Australian Centre for Gay and Lesbian Research, University of Sydney, 1993, pp. 115-148.

Moore C., "Feloniously, Wickedly and Against the Order of Nature": A Research Agenda for Gay Studies in Queensland, Hecate, 1994, 20, 1, pp. 139-150.

Moore C., Poofs in the Park: Documenting Gay 'Beats' in Queensland, Australia, GLQ: A Journal of Lesbian and Gay Studies, 1995, 2, 2, pp. 319-339.

Moore C., The Frontier Makes Strange Bedfellows: Masculinity, Mateship and Homosexuality in Colonial Queensland, in Wotherspoon G. (Ed.), Gay Perspectives III, Department of Economic History and the Australian Centre for Lesbian and Gay Research, University of Sydney, 1996, pp. 17-44.

Moore C., Colonial Manhood and Masculinities, in Moore C., Saunders K. (Eds), Australian Masculinities: Men and their Histories, Journal of Australian Studies, 1998, 56, pp. 35-5.

Moore C., Sunshine and Rainbows: The Development of Gay and Lesbian Culture in Queensland, St Lucia, University of Queensland Press, 2001.

Norton R., Mother Clap's Molly House: The Gay Subculture in England, 1700-1830, London, GMP, 1992.

Oakes R. F., "Things Fearful to Name": Sodomy and Buggery in Seventeenth-century New England, Journal of Social History, 1978, 12, 1, pp. 268-281.

Peniston W. A., Love and Death in Gay Paris: Homosexuality and Criminality in the 1870s, in Merick J., Ragan B.T. jr. (Eds), Homosexuality in Modern France, New York \& Oxford, Oxford University Press, 1996, pp. 128-145.

Queensland State Archives, Criminal Depositions, John Lowry, Briefs, Depositions and Associated Papers, in Criminal Cases, 1 February to 28 February 1907, Brisbane, SCT/CCC183.

Schofield G.M., An Overview of the Methods of State Child Care in Queensland, 1864-1965, BSoc. Work Thesis, University of Queensland, 1971.

Sibalis M. D., The Regulation of Male Homosexuality in Revolutionary and Napoleonic France, 1789-1815, in Merick J., Ragan B.T. jr. (Eds), Homosexuality in Modern France, New York \& Oxford, Oxford University Press, 1996, pp. 80-101.

Smith F. B., 1976, Labouchere's Amendment to the Criminal Law Amendment Bill, Historical Studies, 17, 67, 165-175.

Spearritt K., The Poverty of Protection: Women and Marriage in Colonial Queensland, 1870-1900, BA Honours thesis, University of Queensland, 1988.

Sturma M., Vice in a Vicious Society: Crime and Convicts in Mid-Nineteenth Century New South Wales, St Lucia (Qld), University of Queensland Press, 1983. 
Trumbach R., Sodomitical Subcultures, Sodomitical Roles, and the Gender Revolution of the Eighteenth Century: The Recent Historiography, in MacCubbin R.P. (Ed.), Unauthorized Sexual Behaviour During the Enlightenment, Eighteenth Century Life, 1985, 9, 3, pp. 108-121.

Trumbach R., Gender and the Homosexual Role in Modern Western Culture: The $18^{\text {th }}$ and $19^{\text {th }}$ Centuries Compared, in Altman D. et al. (Eds), Homosexuality, Which Homosexuality?, Amsterdam \& London, Uitgeverij an Dekker/Schoner and GMP 1989a, pp. 149-169.

Trumbach R., The Birth of the Queen: Sodomy and the Emergence of Gender Equality in Modern Culture, 1660-1750, in Duberman M.B. et al. (Eds), Hidden From History: Reclaiming the Gay and Lesbian Past, New York, New American Library, 1989b, pp. 129-140.

Trumbach R., Sex and the Gender Revolution: Heterosexuality and the Third Gender in Enlightenment London, Vol. 1, Chicago \& London, University of Chicago Press, 1998.

Trumbach R., London, in Higgs D. (Ed.), Queer Sites: Gay Urban Historians since 1600, London \& New York, Routledge, 1999, pp. 89-111.

Vamplew W. (Ed.), Australians: Historical Statistics, Sydney, Fairfax, Syme \& Weldon Associates, 1987.

Wafer J., Southgate E., Coan L.(Eds.), Out in the Valley: Hunter Gay and Lesbian Histories, Newcastle (NSW), Newcastle Region Library, 2000.

Weeks J., Coming Out: Homosexual Politics in Britain from the Nineteenth Century to the Present, London, Quartet Books, 1990.

Willett G., The Darkest Decade: Homophobia in 1950s Australia, Australian Historical Studies, 1997, 109, pp. 120-132.

Willett G., Living Out Loud: A History of Gay and Lesbian Activism in Australia, St. Leonards (NSW), Allen \& Unwin, 2000.

Wotherspoon G., A Sodom in the South Pacific: Male Homosexuality in Sydney, 1788-1809, in Aplin G. (Ed.), A Difficult Infant: Sydney Before Macquarie, Sydney, New South Wales University Press, 1988, pp. 91-101.

Wotherspoon G., “This Nest of Perverts”: Policing Male Homosexuality in Cold War Australia, Working Papers in Australian Studies, No. 32, London, Sir Robert Menzies Centre for Australian Studies, 1990.

Wotherspoon G., 'City of the Plain': History of a Gay Sub-Culture, Sydney, Hale \& Iremonger, 1991.

\section{NOTES}

1. Fogarty (1992); Bavin-Mizzi (1993); Baskerville (1998); Carr (2000); Connors (1993).

2. Oakes (1978); Gilbert (1976); Meer (1989); Hekma (1999, pp. 63-65); Harvey (1978); D’Emilio, Freedman (1988, p. 123, 380 ftn 26, 408); Ingram (2003); Peniston (1996); Sibalis (1996).

3. Harvey (1978, pp. 944-946).

4. Trumbach $(1985 ; 1989 a ; 1989 b ; 1998 ; 1999)$.

5. Weeks (1990, p. 36).

6. Wotherspoon (1988); Hughes (1987, pp. 264-72, 529-32, 536-38); McLachlan (1989, pp. 72-73, 112-13); Connors (1993).

7. Aldrich (1993; 2003).

8. This was the phrase used by nonagenarian Miss Eva Black in the mid-1970s when discussing her recollections of George Seymour (Lord Yarmouth and later $7^{\text {th }}$ Marquess of Hertford), who 
lived in Mackay briefly in the 1890s. She had memories of Seymour performing dances in a sequined outfit with butterfly wings, in front of the limelights, and of him holding all-male parties, which caused some consternation in the district. Moore (2001, pp. 46-48).

9. Moore (2001, pp. 46-48).

10. Chauncey (1994, pp. 1-13, $385 \mathrm{ftn} 2)$.

11. Moore (2001, pp. 90-104); Faro, Wotherspoon (2000); Wafer, Southgate, Coan (2000).

12. Moore $(1993 ; 1994 ; 1995 ; 1996 ; 2001)$.

13. Sturma (1983, p. 98).

14. Collins (1991a, b).

15. For example, The Criminal Law Amendment Act of 1945, 9 Geo.VI. No.11.

16. An Act for Consolidating and Amending the Statutes in England Relative to Offences against the Person of 1828 ( 9 Geo IV cl. 31 c. 115). New South Wales also had a 1837 amending Act, which does not deal directly with sexual offences and refers back to the 1829 Act. An Act to Amend the Laws Relating to Offences Against the Person (7 Geo IV \& 1 Vic No. 85 [1837]). Five Queensland cases were found from 1860-65 under the old legislation. Two were for sodomy of a male, one for sodomy of a woman (mentioned above), and two for attempted sodomy of males. Only two sentences are extant: two years with hard labour, and the death sentence.

17. Barber (1967, pp. 18, 53); Emsley (1996, pp. 278-79).

18. Sturma (1983, p. 98).

19. Harvey (1978, p. 941).

20. Smith (1976).

21. See Queensland's Criminal Law Amendment Act of 1891 (55 Vic No 24) and An Act to Establish a Code ofCriminal Code of 1899 (63 Vic No 9), Clause 211. The Labouchere amendment took even longer to be adopted in other Australian jurisdictions; for instance not until 1919 in the State of Victoria. Carr (2000, pp. 38-39).

22. Joyce (1984).

23. Willett (2000, pp. 219-38); Moore (2001, pp. 161-89).

24. Vamplew (1987, pp. 25, 26, 41).

25. Some caution is needed here. The town or city in which a case was tried was not necessarily that in which the offence was committed. For example, an offence committed in a rural area would have been tried in an urban setting, the locale of the courthouse. As noted earlier, the Supreme and District Courts only sat in a few urban centres, but each had a large catchment area. 26. Finnane, Garton (1992a, b).

27. Moore (1995, p. 332).

28. Spearritt (1988, p. 31).

29. $27 \%$ were found not guilty and in $3 \%$ of cases we could not establish a verdict.

30. Such sentences covered monetary fines, suspended sentences, being placed into state care, probation, medical treatment and release under their own recognizances. On occasion a combination of two or more of the above constituted a sentence.

31. Goldman (1978); Schofield (1971).

32. Section 62 reads: "Whosoever shall be convicted of the abominable crime of buggery committed either with mankind or with any animal shall be liable at the discretion of the court to be kept in penal servitude for life or for any term not less than ten years."

33. Section 208 - "Unnatural Offences" - had three sub-sections: "Has carnal knowledge of any person against the order of nature; or, Has carnal knowledge of an animal; or, Permits a male person to have carnal knowledge of him or her against the order of nature."

34. $17 \%$ of cases proved to be inconclusive.

35. $4 \%$ of cases proved to be inconclusive.

36. The 1875 case concerned middle-aged John Fitzgerald of Goondiwindi, tried in the Circuit Court, Toowoomba, 26 July 1875, QSA JUS S2; CCT4/N25. The Magistrate noted to the Attorney 
General that he was sure the thirteen year-old youth involved was a consenting party, but this did not alter the sentence.

37. Despite wide canvassing of opinion amongst Queensland lawyers, and discussions at the $22^{\text {nd }}$ Annual Conference of the Australian and New Zealand Law and History Society in Brisbane during July 2003, we have been unable to find a satisfactory explanation of why sentences awarded under the 1865 Act are below the minimum specified: 10 years penal servitude. However, Finnane (1997, pp. 32-33) notes increasing leniency in sentencing in colonial Australia, as do Freiberg and Ross (1999, pp. 86-106).

38. Moore (1998).

39. Moore (1996, pp. 31-32); D’Emilio, Freedman (1988, pp. 121-124).

40. $15 \%$ of defendants received either suspended sentences or were required to undergo medical treatment.

41. Section 63 reads: "Whosoever shall attempt to commit the said abominable crime or shall be guilty of any assault with intent to commit the same or any indecent assault upon any male person shall be guilty of a misdemeanour and being convicted thereof shall be liable at the discretion of the court to be kept in penal servitude for any term not exceeding ten years and not less than three years or to be imprisoned for any term not exceeding two years with or without hard labour."

42. Section 209 - "Attempts to Commit Unnatural Offences" - reads: "Any person who attempts to commit any of the crimes defined in the last proceeding section is guilty of a crime, and is liable to imprisonment with hard labour for seven years."

43. $12 \%$ of cases proved to be inconclusive.

44. $4 \%$ of cases proved to be inconclusive.

45. Section 211-“Indecent Practices between Males" - reads: "Any male person who, whether in public or private, commits any act of gross indecency with another male person, or procures another male person to commit any act of gross indecency with him, or attempts to procure the commission of any such act by any male person with himself or with another male person, whether in public or private, is guilty of a misdemeanour, and is liable to imprisonment with hard labour for three years."

46. Moore (2001, pp. 120-141).

47. Section 210 - "Indecent Treatment of Boys under Fourteen" - reads: "Any person who unlawfully and indecently deals with a boy under the age of fourteen years is guilty of a crime, and is liable to imprisonment with hard labour for seven years."

48. Barber (1967, p. 98).

49. The closest Queensland comparison available is Yorick Smaal's unpublished statistics on rape and attempted rape cases between 1890 and 1915. There is however a considerable difference between rape and attempted rape - largely non-consensual acts by men against women, and crimes related more to power relations than to sexual desire - and homosexual offences. While some of the homosexual cases may also have involved rape or involuntary participation, there is no evidence to support this. Accepting these differences, generally the rape and attempted rape sentences are heavier than those for anal intercourse and attempted anal intercourse. This may indicate that society regarded rape as a more serious offence than homosexual activity. There were 25 rape charges 1890 to 1900: 11 guilty verdicts were delivered; there were 7 death sentences, one of which was commuted, and other sentences varied between 10 and 2 years with hard labour. Between 1901 and 1915 there were 46 rape charges: in 27 cases guilty sentences were delivered with an average sentence of 6 years, almost all with hard labour. Between 1890 and 1900 there were 21 attempted rape charges: 11 guilty verdicts were delivered; the average sentence was 2 years and 10 months, and 8 of the sentences included hard labour. There were 37 attempted rape charges, 1901-1915, with 32 guilty verdicts; the average sentence length was 2 years, almost all with hard labour. I am indebted to Yorick Smaal for providing these statistics. 
50. Moore (2001, pp. 51-59).

51. Halperin, 2000, p. 110).

52. Moore (2001, pp. 93-94, 98-100).

53. Berube (c1983; 1990).

54. Willett (1997); Wotherspoon (1990; 1991, pp. 109-38).

55. Willett (2000).

56. Chauncey (1994, pp. 1-13, 385, ftn 2).

\section{ABSTRACTS}

Until a series of law reforms between the 1970s and 1990s, male homosexual activity was a criminal offence in all Australian jurisdictions and subject to severe penalties. This paper is an analysis of 464 cases between 1860 and 1954 from the colony/state of Queensland. The data is organized by offence and broken down into subcategories relating to the regions of Queensland, time periods, 1860-1900 and 1901-1954, the age of the defendant, and the severity of the sentence. The paper is illustrated by fourteen pie graphs. Although there is a growing literature on gay issues, large-scale evidence of the treatment of homosexuality by the criminal justice system is rare, and most previous studies have only sampled the cases preserved in criminal justice records. This ninety-five year span of cases is unique in Australia and unusually detailed by any standards. The evidence indicates that the police carefully chose the possible range of charges to ensure convictions, targeted various age groups, manipulated the evidence, and tried to control the emerging gay subculture. However, the sentences, although still severe were lenient within the possible range, and show that the judges were aware that male homosexuality was not such an "abominable crime". During the twentieth century, the legal system attempted to understand homosexuality and moderated sentences accordingly. The findings help locate the timing of the emergence of the modern Australian male homosexual, when erotic categories are reorganized, gender and gender roles loose significance for categorizing sexual acts, and sexual object choice becomes detached from gender identity, allowing men to be homosexual while maintaining normative behaviour patterns.

Avant l'intervention d'une série de réformes législatives entre les années 1970 et 1990, l'homosexualité masculine constituait une infraction pénale passible de peines sévères dans toute l'Australie. Cet article analyse 464 affaires poursuivies entre 1860 et 1954 dans la colonie, puis l'État, du Queensland. Les données sont organisées selon le type d'infraction et réparties selon la région, la période (1860-1900 et 1901-1954), l'âge des accusés et la sévérité des sentences. La durée de la période étudiée (95 ans) et le caractère détaillé des données sont sans précédent pour l'Australie. Les données démontrent que la police sélectionnait soigneusement les qualifications retenues, de manière à garantir une condamnation, qu'elle ciblait différents groupes d'âge, manipulait les preuves et s'efforçait de contrôler l'émergence d'une sous-culture homosexuelle. Toutefois, quoique sévères, les condamnations étaient modérées eu égard à la marge de liberté des juges et montrent que ceux-ci étaient conscients que l'homosexualité n'était pas le "crime abominable» prétendu. Au cours du XX $\mathrm{XX}^{\mathrm{e}}$ siècle, le système pénal s'efforça de comprendre l'homosexualité et les condamnations furent atténuées en conséquence. Ces résultats permettent de préciser la temporalité de l'émergence de l'homosexuel masculin australien moderne, au cours de laquelle les catégories érotiques furent réorganisées, le genre et 
les rôles sexuels perdirent de leur importance dans la catégorisation des actes sexuels et les choix d'objets sexuels se détachèrent de l'identité de genre, évolutions qui permirent aux hommes d'être homosexuels tout en conservant des modèles de comportement normatifs.

\section{AUTHORS}

\section{CLIVE MOORE}

Associate Professor, School of History, Philosophy, Religion and Classics, The University of Queensland, St Lucia QLD 4072, Australia, c.moore@uq.edu.au

Dr Clive Moore is an Associate Professor in the School of History, Philosophy, Religion and Classics at the University of Queensland, Brisbane, Australia. He has published in Pacific and Australian history and is a specialist in Queensland, Melanesian and gender history. His most recent books are Happy Isles in Crisis: The Historical Causes for a Failing State in Solomon Islands, 1998-2004 (2004), New Guinea: Crossing Boundaries and History (2003) and Sunshine and Rainbows: The Development of Gay and Lesbian Culture in Queensland (2001). His current major projects are a history of Malaita Province, Solomon Islands, and a Historical Dictionary of the Solomon Islands.

\section{BRYAN JAMISON}

Dr Bryan Jamison is Principal Policy Officer with the Community Engagement and Development Policy Unit, Department of Communities, Queensland Government. He has published on sport and plebeian protest in colonial Queensland for Sporting Traditions: the Journal of the Australian Society for Sports History; on the moral reformation movement in colonial Brisbane for the Journal of Popular Culture and, with Clive Moore, Raymond Evans and Kay Saunders, a monograph - 1901 Our Future's Past - documenting the Australian pathways from colonial status to a federated nation of states. His current interests include the theory and practice of designing public policy to empower communities and citizens. 